Pak. j. sci. ind. res. Ser. A: phys. sci. 2021 64A(2) 110-118

\title{
Response of Salts in Saline Soil Using Different Irrigation Scheduling in Semi-Arid Zone of Pakistan
}

\author{
Kamran Baksh Soomro ${ }^{a *}$, Sina Alaghmand ${ }^{\mathrm{b}}$, Muhammad Mujtaba Shaikh ${ }^{\mathrm{c}}$, \\ Sanyogita Andriyas ${ }^{\mathrm{d}}$ and Amin Talei ${ }^{\mathrm{e}}$ \\ ${ }^{a}$ Institute of Plant Introduction, Southern-zone Agricultural Research Center, PARC, Karachi \\ ${ }^{\mathrm{b}}$ Department of Civil Engineering, Monash University, VIC 3800, Melbourne, Australia \\ ${ }^{\mathrm{c}}$ Department of Basic Sciences and Related Studies, Mehran University of Engineering and Technology, \\ Jamshoro, Pakistan \\ ${ }^{\mathrm{d}}$ School of Engineering and Technology, Asian Institute of Technology, Pathumthani, Thailand \\ ${ }^{\mathrm{e}} \mathrm{School}$ of Engineering, Monash University Malaysia, Jalan Lagoon Selatan, Bandar Sunway, 47500 \\ Selangor Darul Ehsan, Malaysia
}

(received March 3, 2020; revised July 21, 2020; accepted July 27, 2020)

\begin{abstract}
The salinity of soil is a crucial challenge for growers irrigating in semi-arid zones. To accomplish salinity, growers require information about salt's basis and processes of the salt mobility through the root zone. Soil salinity can be managed by exceptional irrigating farming practices including irrigation scheduling to leach down salts through the root zone. This study aimed at examining the salts movement in saline soil in a semi-arid region in Sindh, Pakistan. This field experiment was conducted during the summer of 2017 on a salt-affected land by using three irrigation treatments of canal water including T1 ( 7 day irrigation interval), T2 (14 day irrigation interval) and T3 (21 days irrigation interval) under 10, 9 and $8 \mathrm{~cm}$ depths of irrigation water, respectively. The texture of soil was silty clay loam having an electrical conductivity (EC) ranging from 7.73 to $20.69 \mathrm{dS} / \mathrm{m}$. However, the $\mathrm{pH}$ of the soil ranged from 7.89 to 8.04 . The findings of a two-way analysis of variance were consistent with the statistical examination of EC and $\mathrm{pH}$ data daywise (7, 14 and 21 days) and depths-wise $(10,9$ and $8 \mathrm{~cm})$. Average reductions in the $\mathrm{EC}$ and $\mathrm{pH}$ of the soil were observed at 7 days interval and $10 \mathrm{~cm}$ depth at $\mathrm{P}<0.05$. Overall, the findings exhibited that, compared to the 14 and 21 day intervals, a 7 day irrigation interval was more effective in terms of salt leaching from the soil profile.
\end{abstract}

Keywords: canal water, irrigation scheduling, root zone, soil salinity

\section{Introduction}

The soil salinity has been recognized as a chief risk for sustainable agriculture particularly in arid and semiarid area (Wang et al., 2008). Salinity is a rigorous threat which not only decreases crop yield but also generates severe effects on the livelihood of agricultural growers (Ziaul and Zaber, 2013).

Saline soils cover 9 million $\mathrm{km}^{2}$ of the land surface of the earth (FAO, 2005) and globally around $40 \%$ of the land area is impacted by high salinity which can be utilized for agricultural production (Cui et al., 2018; Lal, 2009).

Salinity problems arise with changes in the concentration of salt in irrigation water (Koç, 2008). Though, there are some instances of salt-impacted soils in locations starting from tropical environments to locations amidst

*Author for correspondence;

E-mail: kamisoomro75@hotmail.com the polar circle (Schofield et al., 2001). Soil salinization happens due to numerous reasons involving increasing temperature and reduced precipitation (Ghafoor et al., 2004). Therefore, farmers are unable to afford agricultural practices (Rashid et al., 2004; Ashraf and Sarwar, 2002).

Effective desalinization of salt-affected soils requires a down motion of salt buildup area to a depth from where desalinization is extremely restricted. If the level of groundwater level is lower, the salt accumulation area travels down to a significant depth with adequate rainfall that is beyond the evapotranspiration of agricultural land (Monteleone and Libutti, 2012). Though, due to high evaporation, shallow groundwater makes salt buildup area hard to move downwards. The agricultural productivity in salt effected soil can be improved through salts leaching by irrigation applications (Hussain et al., 2016). Many countries including Australia, China, India, Mexico, Turkey, and Pakistan 
are also encountering salt-related agricultural issues (Rhoades, 1998).

Being an agricultural country, the land of Pakistan is irrigated by river Indus and its branches propose a chance to cultivate several types of crops under diverse environments. The crop yield has been deteriorating for last three decades, nevertheless, this reduction during recent years has been significant due to salinity which considered a key issue of agriculture. Research indicated that from total of 79.6 Mha land area, about 6.3 Mha is troubled by salinity in Pakistan (Khan, 1993). Around 5.1Mha area of Sindh is affected by salinity. From this area, almost 3.23 Mha and 1.87 Mha area is slightly and extremely saline, respectively (Alam and Khan, 2006). The production of agriculture utilizing saline irrigation water has been reduced during the last couple of years. It is proposed to start decreasing when soil pH will surpass 8.5 or when the EC of soil is higher than $4 \mathrm{dS} / \mathrm{m}$ (Rajpar et al., 2006; Sairam et al., 2002).

Salinity on the surface of the soil is produced by the capillary action in regions with high water-tables (Aslam, 1998). This phenomenon is quite common in regions having reduction in arid period in lands covered by high waterlogged sand. Numerous approaches can help in adapting to salinity including introduction of bio-saline agriculture and promotion of salt-tolerant species like sesbania. This can produce high fodder of biomass at 7.5 ton/ha (van Steenbergen et al., 2015).

In Indus plain, water level is rising in saline ground water zones at a higher rate compared to freshwater zones. This has been deteriorating the land and irrigation water quality specifically for the landholders, in the affected areas (Qureshi et al., 2008). Therefore, keeping the facts in view, an attempt has been made to investigate the salt movement, in the salt affected soil, in semi-arid areas. Hence, the current study aimed to assess the impact of varying irrigation schedules of time on the physicochemical properties of saline soil and salt leaching in the soil profile. This work demonstrates the alternative managements by suppressing the salts under the root zone so that efficient agricultural practices can be used.

\section{Materials and Methods}

Experiment site. The field experiment was carried out at Tando-Allahyar, Sindh, Pakistan during the summer of 2017. The site is located at longitudes of 6805116E to $68022^{\prime} 03 \mathrm{E}$ and latitudes $25017^{\prime} 33 \mathrm{~N}$ to $25037^{\prime} 43 \mathrm{~N}$ in a semi-arid zone. Due to a hot climate, the evaporation rate was higher, with the mean maximum temperature ranges from $38{ }^{\circ} \mathrm{C}$ to $43{ }^{\circ} \mathrm{C}$, whereas the mean annual rainfall was about $250 \mathrm{~mm}$. This site was $200 \mathrm{~km}$ away from the Arabian sea.

The selected site was highly saline, and the water-table depth of the experimental site was $100 \mathrm{~m}$. Hence, this study did not consider groundwater. The soil of the area was clay loam and contained from 50-80 percent of silt. The experimental plot was designed considering two variable aspects (i.e., amount of water and irrigation schedules of times) repeated thrice (i.e., R1, R2 and R3) in a Randomized Complete Block Design (RCBD).

The treatment involved three treatments of irrigation water (i.e., T1 7, T2 14 and T3 21 day irrigation intervals). The size of the experimental field plots was $26 \times 26 \mathrm{~m}$ and the plots were separated into 3 equal blocks. Individually, every block was further divided into subplots with $1 \mathrm{~m} \times 1 \mathrm{~m}\left(1 \mathrm{~m}^{2}\right)$ each with $2 \mathrm{~m}$ between plots and was separated by levees as shown in Fig. 1.

Soil sampling. Prior to each application of irrigation water, the samples of soil were taken from every plot at the soil depths of $0-30,30-60$, and $60-90 \mathrm{~cm}$, respectively in separate pots for the determination of soil moisture. The samples were collected in small bags for chemical investigation. Soil specimens from specific depth were mixed well to make a compound specimen. Next, the compound specimens were taken to laboratory and examined (Jackson, 1958). The Bouyoucos hydrometer method, recommended by Richards (1969), was used to analyze the soil-texture.

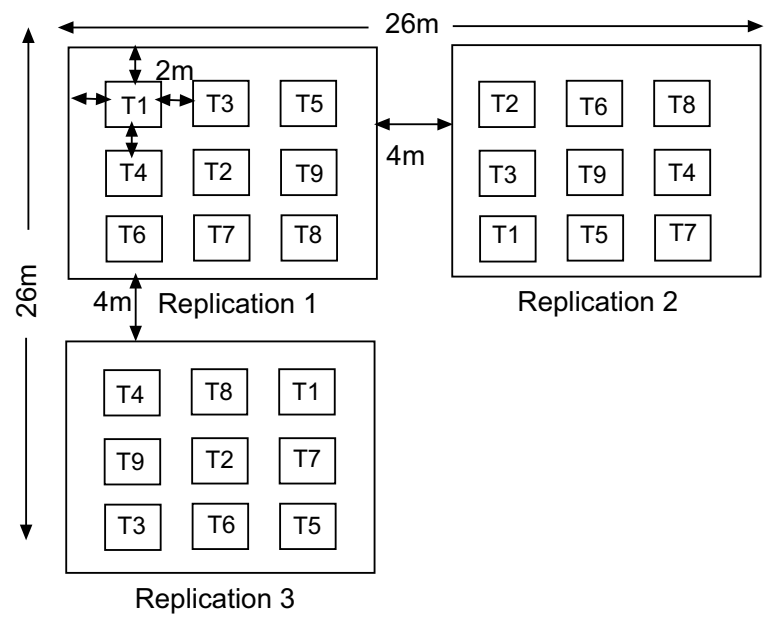

Fig. 1. Layout of the experimental site. 
Electrical conductivity and $\mathrm{pH}$ of the soil. The electrical conductivity (EC) shows salinity, thus, its concentration depicts the salinity level. Irrigation water and soil with $\mathrm{ECe}>4.0 \mathrm{dS} / \mathrm{m}$ is treated to be the saline. Whereas, $\mathrm{pH}$ shows acidity (sodicity) and $\mathrm{pH}$ of 7.0 is considered neutral. EC was calculated by digital EC meter (model HI-8333) and $\mathrm{pH}$ was examined by digital pH meter (model SP-34 sunteor) as advised by Richards (1969).

Cations and anions of soil. Cation exchange capacity (CEC) is an overall capability of certain soil to keep exchangeable cations. It impacts the soil's capacity to keep necessary nutrients and provides protection from soil acidification. Whereas, in anions, the amount of negative charge depends on soil texture which is related to soil particle surface area. Carbonates plus bicarbonates, calcium and chlorides were investigated by the titration method, whereas sodium was examined by EEL-Flame photometer as advised by Richards (1954).

Sodium adsorption ratio and exchangeable sodium percentage. The sodium adsorption ratio (SAR) of the soil indicate the sodicity and its values assess the intensity of sodicity in soil. The SAR shows the relation between sodium ions $\left(\mathrm{Na}^{+}\right)$and calcium plus magnesium ions $\left(\mathrm{Ca}^{+++} \mathrm{Mg}^{++}\right)$. This sodicity of the soil represents as Exchangeable sodium percentage (ESP). The SAR below 7.0 and ESP below 15.0 is considered non-sodic (Davis et al., 2007).

The sodium adsorption ratio (SAR) and exchangeable sodium percentage (ESP) were assessed through the equation presented by Richards (1954).

$$
\begin{aligned}
& \mathrm{SAR}=\frac{\mathrm{Na}^{++}}{\sqrt{\left(\mathrm{Ca}^{++}+\mathrm{Mg}^{++}\right) / 2}} \cdots \cdots \cdots \cdots \cdots \cdots \cdots \cdots \cdots \cdots \cdots \cdots \cdots \cdots \cdots \cdots \cdots \cdots \\
& \mathrm{ESP}=\frac{100(-0.0126+0.01475 \times \mathrm{SAR})}{1+(-0.0126+0.01476 \times \mathrm{SAR})} \cdots \cdots \cdots \cdots \cdots . . . \mathrm{eq} .2
\end{aligned}
$$

Quality of irrigation water. The condition of water for application of irrigation has a vital role in leaching salts. Water-table was around $100 \mathrm{~m}$ deep and considered to be negligible. In this study, canal irrigation water samples were taken periodically during the experiment. These water samples were investigated for the $\mathrm{ECW}$, $\mathrm{pH}$, and SAR parameters (Laboratory, 1954).

Irrigation scheduling. Irrigation scheduling is specifying the time and quantity of water to be given for irrigation. The texture of the soil is an important factor when determining the rate and amount of irrigation applications. In Pakistan, the irrigation system allows water application on a rotation base with 7 days irrigation interval. Therefore, the time schedules were specified in such a way that the irrigation water could be accessible to the growers in accordance with the irrigation time schedules designated for the field experiment. The observation initiated following the site selection and was done after the preparation of plots. Overall, three irrigations were applied at 7, 14 and 21 day schedules of irrigation, respectively. Three pore volumes were deigned to apply water for irrigation. The ultimate depth of irrigation water needed for every plot was measured by using the formula given by (Vogeler, 2001).

Pore volume $=$ cross sectional area $\mathrm{x}$ depth profilevolume of solids eq. 3

The irrigation application of water rates was 8,9 and $10 \mathrm{~cm}$ depth of irrigation water on $1 \mathrm{~m}^{2}$ area of each. The soil samples were collected at the depths of 0-30, $30-60$, and $60-90 \mathrm{~cm}$ for the soil moisture contents by using core sampler from every experimental plot. These soil specimens were transferred to a laboratory for investigation. The equation given by Reeb et al. (1999) was used to ascertain soil's moisture content.

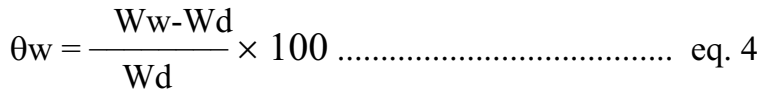

where:

$\theta \mathrm{W}$ is the soil moisture content (\%); $\mathrm{WW}$ is the weight of wet soil specimen $(\mathrm{g})$ and $\mathrm{Wd}$ is the weight of oven dried soil specimen $(\mathrm{g})$.

Statistical analysis. Using SPSS Version 25.0, a twoway analysis of variance (ANOVA) was run to assess the significance of irrigation schedules and depth of irrigation water effects on soil $\mathrm{EC}$ and $\mathrm{pH}$.

\section{Results and Discussion}

Soil qualities of the experiments are shown in Table 1. The texture for complete profile depth $(0-90 \mathrm{~cm})$ was determined as clay to silty clay loam. Capacity of field as well as its wilting point was 24 and $14.2 \%$, respectively. The moisture content before irrigation application was $10.6 \%$ as shown in Table 1 . The soil's moisture content was less than $15 \%$. The bulk density 
Table 1. Physical characteristics of the experimental soil

\begin{tabular}{llllll}
\hline \hline $\begin{array}{l}\text { Soil depth } \\
(\mathrm{cm})\end{array}$ & $\begin{array}{l}\text { Moisture } \\
\text { content }(\%)\end{array}$ & $\begin{array}{l}\text { Field } \\
\text { capacity }(\%)\end{array}$ & $\begin{array}{l}\text { Wilting } \\
\text { point }(\%)\end{array}$ & $\begin{array}{l}\text { Bulk density } \\
(\mathrm{g} / \mathrm{cm})\end{array}$ & $\begin{array}{l}\text { Textural class } \\
0-30\end{array}$ \\
\hline 3.0 & 22 & 13.4 & 1.13 & Clay loam \\
$30-60$ & 10.0 & 24 & 14.2 & 1.16 & Silty clay loam \\
$60-90$ & 15.0 & 24 & 14.1 & 1.19 & Silty clay loam \\
$0-90$ & 10.6 & 26 & 15.3 & 1.16 & Silty clay loam \\
\hline \hline
\end{tabular}

of soil, however, was $1.16 \mathrm{~g} / \mathrm{cm}$ with mean over $90 \mathrm{~cm}$ depth which indicates that the soil was considered clay to silty clay loam.

The quality of irrigation water has a principal role in the salt movement in soil. Table 2 demonstrates the analytical parameter of water specimens and shows that water was non-saline (i.e., E. $\mathrm{Ciw}<1.5 \mathrm{dS} / \mathrm{m}, \mathrm{pH}$ up to 7.2 , and $\mathrm{SAR}<1.0$ ). Hence, these values showed that the quality of irrigation water was under safe limits to perform salt leaching.

Anions and cations of soil. Chemical examination of the samples of soil, which were collected preceding and succeeding irrigation application for 0-30, 30-60, and 60-90 cm, was performed (as shown in Fig. 2). By applying $10 \mathrm{~cm}$ depth of irrigation water with 21 days irrigation interval, the mean carbonate plus bicarbonate slightly decreased from 9.0 to $8.8 \mathrm{meq} / \mathrm{L}$, while the mean chlorides cut down from 93.69 to $69.48 \mathrm{meq} / \mathrm{L}$ and the mean sulfate increased from $29.52 \mathrm{meq} / \mathrm{L}$ to $41.63 \mathrm{meq} / \mathrm{L}$ (as shown in Fig. 2). The mean calcium plus magnesium and sodium values for 21 day irrigation time schedule slightly reduced from 85.93 to 36.47 meq/L under the $10 \mathrm{~cm}$ depth of irrigation water. However, sodium was a dominant cation which slightly reduced from 85.80 to $83.52 \mathrm{meq} / \mathrm{L}$ after 21 days irrigation interval as shown in Fig. 2.

Sodium adsorption ratio and exchangeable sodium percentage. The sodium adsorption ratio (SAR) and exchangeable sodium percentage (ESP) of the soil are shown in Fig. 3. The mean (SAR) before irrigation was 19.83 with the application of $10 \mathrm{~cm}$ depth of irrigation

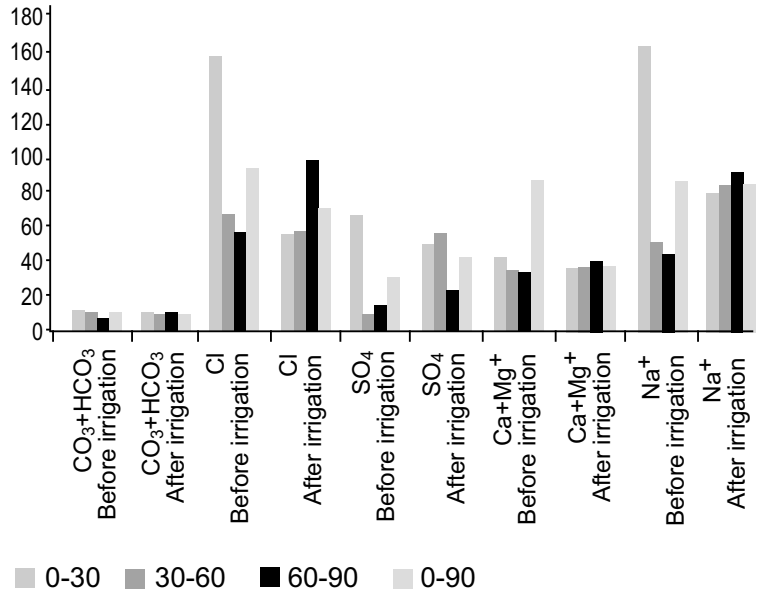

Fig. 2. Chemical analysis of soil samples taken before and after 21 day irrigation at a 10 $\mathrm{cm}$ depth of irrigation water.

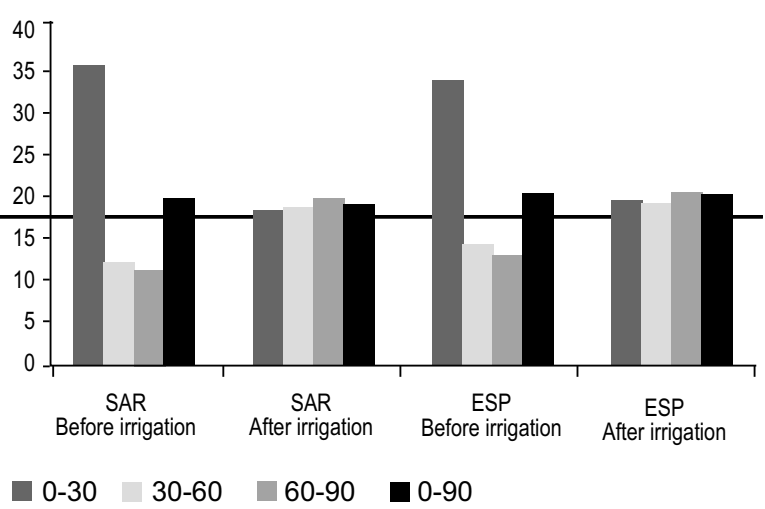

Fig. 3. SAR and ESP of soil samples taken before and after 21 day irrigation at a $10 \mathrm{~cm}$ depth of irrigation water.

Table 2: Analysis of irrigation water quality

\begin{tabular}{lllllll}
\hline \hline Sampling date & Source of water & & Parameters & & \multirow{2}{*}{ Water quality } \\
\cline { 3 - 6 } & & ECiw $(\mathrm{dS} / \mathrm{m})$ & $\mathrm{pH}$ & $\mathrm{SAR}$ & $\mathrm{RSC}$ & \\
\hline $04-05-17$ & Canal water & 0.50 & 7.1 & 1.8 & Nil & Fresh \\
$11-05-17$ & Canal water & 0.48 & 7.2 & 1.8 & Nil & Fresh \\
$30-05-17$ & Canal water & 0.53 & 7.1 & 1.9 & Nil & Fresh \\
\hline \hline
\end{tabular}


water after the 21 day interval it was somewhat reduced to 19.1 at a $0-90 \mathrm{~cm}$ depth of soil. Whereas an (ESP) value somewhat reduced from 20.40 to 20.04 at a $0-90$ $\mathrm{cm}$ depth of soil and this reduction can be clarified through reality that the proportion of $\mathrm{Na}^{+}$to $\mathrm{Ca}^{+}$in the soil is $<1$ in the non-saline irrigation water as mentioned in Fig. 3. The above results indicate that the top layer of soil had more soluble carbonates and bi-carbonates and this is in line with (Campos et al., 2003) who reported that irrigation with saline water caused in instant buildup of salts, specifically in topsoil layer. The adverse effects were mostly related accumulation of salts in soil which might result in less growing rate in crops (Maas and Tanji, 1990). Though, irrigation supply of water having EC less than $1 \mathrm{dS} / \mathrm{m}$ reduced level of $\mathrm{Na}^{+}$and $\mathrm{Cl}^{-}$(Belhouchette et al., 1997).

Electrical conductivity and $\mathbf{p H}$ of the soil. The EC of soil at 3 depths (i.e., $0-30 \mathrm{~cm}, 30-60 \mathrm{~cm}$ and $60-90$ $\mathrm{cm}$ ) was calculated before and after irrigation under 8 , 9 , and $10 \mathrm{~cm}$ depth of irrigation water, respectively. Before irrigation, the minimum and maximum $\mathrm{EC}$ was $7.73 \mathrm{dS} / \mathrm{m}$ at $60-90 \mathrm{~cm}$ and 20.69 at $0-30 \mathrm{~cm}$, respectively. Whereas, before irrigation, a minimum and maximum mean of $\mathrm{pH}$ was 7.89 at $0-30 \mathrm{~cm}$ depth and 8.04 at $60-90 \mathrm{~cm}$ depth, respectively. The total mean was 7.99 at $0-90 \mathrm{~cm}$.

A comprehensive statistical examination was conducted. Initially, we focused on only comparing the $\mathrm{EC}$ and $\mathrm{pH}$ data of the three treatments against the data before any treatment. The results of the descriptive statistics of the $\mathrm{EC}$ and $\mathrm{pH}$, before and after irrigation treatments, daywise and depths-wise, are summarized in Table 3. It is clear from Table 3, that the mean EC and the mean $\mathrm{pH}$ of the soil are minimal in the case of 7 days interval. The maximum mean decline was observed in the EC and $\mathrm{pH}$ overall compared to the mean $\mathrm{EC}$ and $\mathrm{pH}$ value appearing before.

Finally, the data of $\mathrm{EC}$ and $\mathrm{pH}$ of soils were analyzed using two-way analysis of variance (2-way ANOVA) suitable for a RCBD with three replications. Following were the hypotheses of this study:

The null hypothesis, $\mathrm{H} 0=$ there is no difference in mean $\mathrm{EC}$ and mean $\mathrm{pH}$ with respect to days' time schedule and depth of irrigation water. Mathematically it is represented by the following equations.

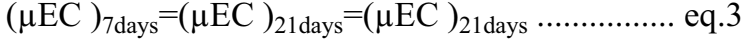

$$
\begin{aligned}
& (\mu \mathrm{pH})_{7 \text { days }}=(\mu \mathrm{pH})_{21 \text { days }}=(\mu \mathrm{pH})_{21 \text { days }} \ldots \ldots \ldots \ldots \ldots \ldots . . . \text { eq. } .5 \\
& (\mu \mathrm{EC})_{10 \mathrm{~cm}}=(\mu \mathrm{EC})_{9 \mathrm{~cm}}=(\mu \mathrm{EC})_{8 \mathrm{~cm}} \ldots \ldots \ldots \ldots \ldots \ldots \ldots . . . . . . . . . . .6
\end{aligned}
$$

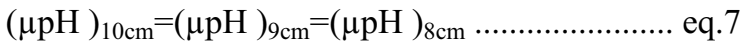

A significance level of 5\% to search for evidence in favor of $\stackrel{\circ}{\mathrm{H}}$ has been set. A P-value of more than 0.05

Table 3: Descriptive statistics of $\mathrm{EC}$ and $\mathrm{pH}$ data before and after treatments with respect to days intervals and depths of irrigation water

\begin{tabular}{lllllllll}
\hline \hline Variables & $\begin{array}{l}\text { Days interval// } \\
\text { Depth }(\mathrm{cm})\end{array}$ & Mean & \multicolumn{2}{l}{$\begin{array}{l}\text { 95\% confidence } \\
\text { interval for mean }\end{array}$} & Median & Range & $\begin{array}{l}\text { Standard } \\
\text { deviation }\end{array}$ \\
\hline EC & Before & 0 & 12.25 & 7.38 & 17.11 & 8.35 & 12.96 & 6.32 \\
& after & 7 days & 4.68 & 4.11 & 5.25 & 4.50 & 2.57 & 0.73 \\
& day-wise & 14 days & 9.14 & 7.48 & 10.81 & 8.73 & 6.48 & 2.16 \\
& & 21 days & 14.48 & 12.97 & 15.99 & 15.40 & 5.36 & 1.96 \\
& After & $10 \mathrm{~cm}$ & 8.00 & 5.34 & 10.65 & 7.96 & 9.11 & 3.45 \\
& depth-wise & $9 \mathrm{~cm}$ & 9.43 & 5.63 & 13.22 & 8.30 & 11.78 & 4.94 \\
& & $8 \mathrm{~cm}$ & 10.88 & 7.26 & 14.50 & 11.75 & 11.94 & 4.71 \\
$\mathrm{pH}$ & Before & 0 & 7.98 & 7.93 & 8.04 & 8.03 & 0.15 & 0.07 \\
& after & 7 days & 7.77 & 7.73 & 7.80 & 7.78 & 0.14 & 0.04 \\
& day-wise & 14 days & 7.97 & 7.90 & 8.03 & 8.00 & 0.30 & 0.08 \\
& 21 days & 7.98 & 7.94 & 8.02 & 8.00 & 0.13 & 0.04 \\
& After & $10 \mathrm{~cm}$ & 7.86 & 7.77 & 7.96 & 7.90 & 0.40 & 0.12 \\
& depth-wise & $9 \mathrm{~cm}$ & 7.91 & 7.82 & 8.00 & 7.99 & 0.30 & 0.11 \\
& 8cm & 7.94 & 7.86 & 8.02 & 8.00 & 0.26 & 0.10 \\
\hline \hline
\end{tabular}

Note: $\mathrm{LL}=$ lower limit; $\mathrm{UL}=$ upper limit. 
Table 4. ANOVA output for the difference between mean ECs day-wise and depth-wise

\begin{tabular}{llllll}
\hline \hline Source & $\begin{array}{l}\text { Type III } \\
\text { sum of } \\
\text { squares }\end{array}$ & df & $\begin{array}{l}\text { Mean } \\
\text { square }\end{array}$ & F & P \\
\hline Model & 2875.54 & 5 & 575.10 & 357.53 & 0.00 \\
Days & 433.03 & 2 & 216.51 & 134.60 & 0.00 \\
Depth & 37.38 & 2 & 18.69 & 11.62 & 0.00 \\
Error & 35.38 & 22 & 1.60 & & \\
Total & 2910.92 & 27 & & & \\
\hline \hline
\end{tabular}

Note: $\mathrm{df}=$ degrees of freedom.

is considered as evidence in support of $\mathrm{H}^{\circ}$. The alternative hypothesis, Ha is simply the negation of $\mathrm{H}$ and supports a significant difference between mean $\mathrm{EC}$ and $\mathrm{pH}$ regarding days' time interval and depth of irrigation water at 0.05 level of significance.

The output of 2-way ANOVA test at 5\% level of significance for the EC of the soil is given in Table 4. This indicates that there is a significant difference in the model data generally with $\mathrm{F}$ equal to 357.535 $(\mathrm{P}<0.05)$. This is specifically, due to the day's interval with $\mathrm{F}$ equal to $134.604(\mathrm{P}<0.05)$ and depth of the irrigation water with $\mathrm{F}$ equal to $11.62(\mathrm{P}<0.05)$. Based on the ANOVA results in Table 4, the null hypothesis is rejected. To explore the mean differences which particularly resulted in this rejection, we performed Least significant difference (LSD) which is a postANOVA test incase ANOVA leads to rejecting the null hypothesis initially.

The results of LSD for EC data are summarized in Table 5. All the mean differences in EC data day-wise and depth-wise are statistically significant with $\mathrm{P}<0.05$. Moreover, it can be seen from Table 5 that the highest negative difference in mean EC of soil appears between days intervals of 7 and 21, and between the irrigation water depths of 10 and $8 \mathrm{~cm}$. This indicated that the EC after 7 days interval and $10 \mathrm{~cm}$ depth of the irrigation water remained lowest among all replications of the irrigation treatment from 7 to 21 days and 10 to $8 \mathrm{~cm}$ depths.

Hence, the 7 day interval results in a positive response in EC compared to the 14 and 21 day irrigation schedules. The concentration of salt in upper layer might be associated with an increased evaporation amount from the saturated layer as reported by (Yazar et al., 2003). Moreover, a high saline irrigation, having EC of 6.0 and $8.0 \mathrm{dS} / \mathrm{m}$, significantly boosted soil salinity during brief growth time. The saline irrigation with an EC of $4.0 \mathrm{dS} / \mathrm{m}$ can be applied with no reductions in maize production if soil salinity is sustained (Hussain et al., 1981). The same trend was also reported by Li et al. (2003) that the saline irrigation for long period could result in possible secondary salinity in the soil. The findings are in harmony with (Ma et al., 2008) who conducted a field experiment in North China Plain. They revealed that the average soil ECe irrigated with

Table 6. ANOVA output for the difference between mean $\mathrm{pH}$ day-wise and depth-wise

\begin{tabular}{llllll}
\hline \hline Source & $\begin{array}{l}\text { Type III } \\
\text { sum of } \\
\text { squares }\end{array}$ & df & $\begin{array}{l}\text { Mean } \\
\text { square }\end{array}$ & F & P \\
\hline Model & 1689.61 & 5 & 337.92 & 108231.60 & 0.00 \\
Depth & 0.02 & 2 & 0.01 & 4.53 & 0.02 \\
Days & 0.24 & 2 & 0.12 & 39.81 & 0.00 \\
Error & 0.06 & 22 & 0.00 & & \\
Total & 1689.68 & 27 & & & \\
\hline \hline
\end{tabular}

Note: $\mathrm{df}=$ degrees of freedom

Table 5. LSD exploration for the difference between means ECs day-wise and depth-wise

\begin{tabular}{|c|c|c|c|c|c|c|}
\hline \multirow[t]{2}{*}{$\begin{array}{l}\text { (I) days interval/ } \\
\text { depth of irrigation } \\
\text { water }\end{array}$} & \multirow[t]{2}{*}{$\begin{array}{l}(\mathrm{J}) \text { days interval/ } \\
\text { depth of irrigation } \\
\text { water }\end{array}$} & \multirow[t]{2}{*}{$\begin{array}{l}\text { Mean difference } \\
(\mathrm{I}-\mathrm{J})\end{array}$} & \multirow[t]{2}{*}{$\mathrm{SE}$} & \multirow[t]{2}{*}{$\mathrm{P}$} & \multicolumn{2}{|c|}{$\begin{array}{l}95 \% \text { Confidence } \\
\text { interval }\end{array}$} \\
\hline & & & & & LL & UL \\
\hline 7days & 14 days & $-4.46^{*}$ & 0.59 & 0.00 & -5.70 & -3.22 \\
\hline 7days & 21 days & $-9.79^{*}$ & 0.59 & 0.00 & -11.03 & -8.55 \\
\hline 14days & 21 days & $-5.33^{*}$ & 0.59 & 0.00 & -6.57 & -4.09 \\
\hline $10 \mathrm{~cm}$ & $9 \mathrm{~cm}$ & $-1.42 *$ & 0.59 & 0.02 & -2.66 & -0.18 \\
\hline $10 \mathrm{~cm}$ & $8 \mathrm{~cm}$ & $-2.88^{*}$ & 0.59 & 0.00 & -4.12 & -1.64 \\
\hline $9 \mathrm{~cm}$ & $8 \mathrm{~cm}$ & $-1.45^{*}$ & 0.59 & 0.024 & -2.69 & -0.21 \\
\hline
\end{tabular}

*. The mean difference is significant at the 0.05 level; Note: $\mathrm{LL}=$ lower limit; $\mathrm{UL}=$ upper limit; $\mathrm{SE}=\mathrm{Standard}$ error. 
Table 7. LSD explorations for the difference between mean $\mathrm{pH}$ day-wise and depth-wise

\begin{tabular}{lllllll}
\hline \hline $\begin{array}{l}\text { (I) days interval/ } \\
\text { depth of irrigation } \\
\text { water }\end{array}$ & $\begin{array}{l}\text { (J)days interval/ } \\
\text { depth of irrigation } \\
\text { water }\end{array}$ & $\begin{array}{l}\text { Mean } \\
\text { difference } \\
\text { (I-J) }\end{array}$ & SE & P & \multicolumn{2}{l}{$\begin{array}{l}95 \% \\
\text { Confidence } \\
\text { interval }\end{array}$} \\
\hline & & & & & LL & UL \\
7 days & 14 days & $-0.19^{*}$ & 0.02 & 0.00 & -0.25 & -0.14 \\
7 days & 21 days & $-0.20^{*}$ & 0.02 & 0.00 & -0.26 & -0.15 \\
14 days & 21 days & -0.01 & 0.02 & 0.67 & -0.06 & 0.04 \\
$10 \mathrm{~cm}$ & $9 \mathrm{~cm}$ & $-0.05^{* *}$ & 0.02 & 0.06 & -0.10 & 0.00 \\
$10 \mathrm{~cm}$ & $8 \mathrm{~cm}$ & $-0.07^{*}$ & 0.02 & 0.00 & -0.13 & -0.02 \\
$9 \mathrm{~cm}$ & $8 \mathrm{~cm}$ & -0.02 & 0.02 & 0.34 & -0.08 & 0.029 \\
\hline \hline
\end{tabular}

*The mean difference is significant at the 0.05 level; ${ }^{* *}$ The mean difference is significant at the 0.1 level; Note: $\mathrm{LL}=$ lower limit; $\mathrm{UL}=$ upper limit; $\mathrm{SE}=$ Standard error.

saline water was more than the ECe of soil irrigated with fresh water.

Table 6. summarizes the output of 2-way ANOVA test at $5 \%$ level of significance for the $\mathrm{pH}$ of the soil. The model indicates that there is a significant difference in the model data generally with $\mathrm{F}$ equal to 108231.605 $(\mathrm{P}<0.05)$. This is specifically due to the day's interval with $\mathrm{F}$ equal $4.53(\mathrm{P}<0.05)$ and depth of the irrigation water with $\mathrm{F}$ equal to $39.815(\mathrm{P}<0.05)$. Based on the ANOVA results in Table 6, the null hypothesis is rejected. For a further and detailed exploration of the differences, the results of LSD for $\mathrm{pH}$ data are given in Table 7.

Most of the mean differences in $\mathrm{pH}$ data day-wise and depth-wise are statistically significant with $\mathrm{P}<0.05$. It can be seen from Table 7 that the maximum negative difference in mean $\mathrm{pH}$ of soil appears between days intervals of 7 and 21, and between the irrigation water depths of $10 \mathrm{~cm}$ and $8 \mathrm{~cm}$, again indicating that the $\mathrm{pH}$ after 7 days interval and $10 \mathrm{~cm}$ depth of the irrigation water remained the lowest among all replications of the irrigation treatment from 7 to 21 days and 10 to $8 \mathrm{~cm}$ depths. At $1 \%$ level of significance, the difference between the mean $\mathrm{pH}$ at $10 \mathrm{~cm}$ and $9 \mathrm{~cm}$ depths were significantly different. On the other hand, there was not a significant difference at 0.05 level of significance between the mean $\mathrm{pH}$ data of 14 and 21 days $(\mathrm{P}=0.677)$ and depths $9 \mathrm{~cm}$ and $8 \mathrm{~cm}(\mathrm{P}=0.342)$.

Overall, the 7 day irrigation interval took $\mathrm{pH}$ closer to the normal. The findings are consistent with past study (Feizi et al., 2007) as authors also reported the need to recognize the volume of fruitful rainfall with irrigation depth, efficient irrigation management practices for achieving productive leaching, and avoid the salts buildup in the root zone. However, the fall in the amount of irrigation water for leaching substantially increases salinity of soil as well as drainage effluent, eventually resulting in yield reduction (Hassanli et al., 2010). Dahiya et al. (1981) reported that leaching efficiency can be improved through intermittent leaching. Furthermore, a gradual water movement is related with considerable salt leaching efficiency along with improved percolation time (Shaygan et al., 2017).

\section{Conclusion}

Overall, the saline soils of Sindh, Pakistan contained a high quantity of salts like sodium chloride and calcium sulfate due to capillary rise mainly owing to lack of rainfall and a high rate of evapotranspiration (ET). Based on the irrigation interval day and depth of irrigation water, three replications for $\mathrm{EC}$ and $\mathrm{pH}$ were measured. The two-way ANOVA and successive LSD indicated that there was statistically a significant difference in $\mathrm{EC}(\mathrm{P}=0.05)$ and in $\mathrm{pH}(\mathrm{P}=0.05)$ in association with irrigation interval day and depth of irrigation water. It was observed that the 7 days interval with irrigation depth of $10 \mathrm{~cm}$ resulted in a maximum decline in the $\mathrm{EC}$ and $\mathrm{pH}$. Results showed that the 7days irrigation interval was more effective for leaching the salts compared with 14 and 21 day intervals. Therefore, cotton, sugarcane, fodder crops, and wheat could be cultivated. The growers and researchers are advised to favor 7 days interval of irrigation for soil reclamation by using irrigation water having less than $1 \mathrm{dS} / \mathrm{m}$ with furrow mode. Thus, before crop sowing, the leaching can be done to control the salts to provide a suitable environment to root-zone.

Conflict of Interest. The authors declare no conflict of interest. 


\section{References}

Alam, S., Khan, M. 2006. Managing Salinity with Soil Conditioners. P III. May: 1-7. Article Published in Dawn Economic and Business Review.

Ashraf, M.Y., Sarwar, G. 2002. Salt tolerance potential in some members of Brassicaceae physiological studies on water relations and mineral contents. In: Prospects for Saline Agriculture, (pp. 237-245). Springer, Dordrecht.

Aslam, M. 1998. Improved water management practices for the rice-wheat cropping systems in Sindh Province, Pakistan. 96 pp. Report No. R-70, 1 a. IIMI, Lahore, Pakistan.

Belhouchette, H., Hamdy, A., Choukr-Allah, R., Mechlia, N.B. 1997. Irrigation method for maize using saline water. Special session: unconventional water resources practices and management: major issues. In: Water Management, Salinity and Pollution Control, Towards Sustainable Irrigation in the Mediterranean Region. Center International de Hautes Études Agronomiques Mediterranéennes Int'l. Conf. Valenzano, Bari, Italy, Sept (pp. 22-6).

Campos, A.A., Pereira, L.S., Gonçalves, J.M., Fabião, M.S., Liu, Y., Li, Y.N., Mao, Z., Dong, B. 2003. Water saving in the Yellow river basin, China. 1. Irrigation demand scheduling. Agricultural Engineering International Journal, 2: 1-30

Cui, S., Zhang, J., Sun, M., Chen, H., Feng, Z., 2018. Leaching effectiveness of desalinization by rainfall combined with wheat straw mulching on heavy saline soil. Archives of Agronomy and Soil Science, 64: 891-902.

Dahiya, I.S., Malik, R.S., Singh, M. 1981. Field studies on leaching behaviour of a highly saline-sodic soil under two modes of water application in the presence of crops. The Journal of Agricultural Science, 97: 383-389.

Davis, J.G., Waskom, R.M., Bauder, T.A., Cardon, G.E. 2007. Managing sodic soils, Colorado State University Cooperative Extension. Crop Series Soil, no. 0.504.

FAO, A. 2005. Global network on integrated soil management for sustainable use of salt-affected soils. FAO Land and Plant Nutrition Management Service Rome, Italy.

Feizi, M., Aghakhani, A., MostafaZadeh-Fard, B., Heidarpour, M. 2007. Salt tolerance of wheat according to soil and drainage water salinity. Pakistan Journal of Biological Sciences: PJBS,
10: $2824-2830$.

Ghafoor, A., Qadir, M., Murtaza G. 2004. Salt-Affected Soils: Principles of Management. Allied Book Centre, Urdu Bazar, Lahore, Pakistan.

Hassanli, A.M., Ahmadirad, S., Beecham, S. 2010. Evaluation of the influence of irrigation methods and water quality on sugar beet yield and water use efficiency. Agricultural Water Management, 97: 357-362.

Hussain, G., Sadiq, M., Hamid, A., Ali, H. 1981. Determination of suitable dose of gypsum in relation to quality of irrigation waters. Mona Reclamation Experimental Project, Pub (112).

Hussain, Z., Khattak, R., Irshad, M., Mahmood, Q. 2016. An, effect of saline irrigation water on the leachability of salts, growth and chemical composition of wheat (Triticum aestivum L.) in salinesodic soil supplemented with phosphorus and potassium. Journal of Soil Science and Plant Nutrition, 16: 604-620.

Jackson, M.L. 1958. Soil Chemical Analysis Prentice, NJ, 498, pp.183-204. Hall. Inc., Englewood Cliffs.

Khan, G.S. 1993. Characteristics and genesis of saline-sodic soils in indus plains of Pakistan, $P h D$ Thesis, University of Agriculture, Faisalabad.

Koç, C. 2008. The environmental effects of salinity load in Great Menderes Basin irrigation schemes. Environmental Monitoring and Assessment, 146: 479-489.

Regional Salinity Laboratory (US). 1954. Diagnosis and improvement of saline and alkali soils (No. 60). US Department of Agriculture.

Lal, R. 2009. Sequestering carbon in soils of arid ecosystems. Land Degradation \& Development, 20: 441-454.

Li, F., Benhur, M., Keren, R. 2003. Effect of marginal water irrigation on soil salinity, sodicity and crop yield. Transactions of Chinese Society of Agricultural Engineering, 19: 63-66.

Ma, W., Mao, Z., Yu, Z., Van Mensvoort, M.E.F., Driessen, P.M. 2008. Effects of saline water irrigation on soil salinity and yield of winter wheat-maize in north China Plain. Irrigation and Drainage Systems, 22: 3-18.

Maas, E., Tanji, K. 1990. Agricultural salinity assessment and management. ASCE Manuals \& Reports on Engineering Practice, 71: 262-304.

Monteleone, M., Libutti, A. 2012. Salt leaching due to rain in Mediterranean climate, is it enough? Italian Journal of Agronomy, 7: 6. 
Qureshi, A.S., McCornick, P.G., Qadir, M., Aslam, Z. 2008. Managing salinity and waterlogging in the Indus basin of Pakistan. Agricultural Water Management, 95: 1-10.

Rajpar, I., Khanif, Y.M., Soomro, F.M., Suthar, J.K. 2006. Effect of $\mathrm{NaCl}$ salinity on the growth and yield of Inqlab wheat (Triticum aestivum L.) variety. American Journal of Plant Physiology, 1: 34-40.

Rashid, M.M., Hoque, A.K.F., Iftekhar, M.S. 2004. Salt tolerances of some multipurpose tree species as determined by seed germination. Journal of Biological Sciences, 4: 288-292.

Reeb, J.E., Milota, M.R.1999. Moisture content by the oven-dry method for industrial testing. 66-74.

Rhoades, J. 1998. Use of saline and brackish water for irrigation: implications and role in increasing food production, conserving water, sustaining irrigation and controlling soil and water degradation. In: Proceedings of the International Workshop on the Use of Saline and Brackish Water for Irrigation, Indonesian National Committee on Irrigation and Drainage, pp. 23-24, Ministry of Public Works Bali, Indonesia.

Richards, L. 1969. Diagnosis and Improvement of Saline and Alkali Soils, No. 60, 160p, US Salinity Laboratory Staff.

Richards, L.A. 1954. Diagnosis and improvement of saline and alkali soils. In: United States Salinity Laboratory Staff Agricultural Handbook No. 60, p. 160, United States Department of Agriculture, USA.

Sairam, R.K., Rao, K.V., Srivastava, G.C. 2002.
Differential response of wheat genotypes to long term salinity stress in relation to oxidative stress, antioxidant activity and osmolyte concentration. Plant Science, 163: 1037-1046.

Schofield, R., Thomas, D., Kirkby, B. 2001. Causal processes of soil salinization in Tunisia, Spain and Hungary. Land Degradation \& Development, 12: 163-181.

Shaygan, M., Reading, L.P., Baumgartl, T. 2017. Effect of physical amendments on salt leaching characteristics for reclamation. Geoderma, 292: 96-110.

Van Steenbergen, F., Basharat, M., Lashari, B.K. 2015. Key challenges and opportunities for conjunctive management of surface and groundwater in megairrigation systems, Lower Indus, Pakistan. Resources 4: 831-856.

Vogeler, I. 2001. Copper and calcium transport through an unsaturated soil column. Journal of Environmental Quality, 30: 927-933.

Wang, Y., Xiao, D., Li. Y., Li, X. 2008. Soil salinity evolution and its relationship with dynamics of groundwater in the oasis of inland river basins: case study from the Fubei region of Xinjiang Province, China. Environmental Monitoring and Assessment, 140: 291-302.

Yazar, A., Gençel, B., Sezen, M.S. 2003. Corn yield response to saline irrigation water applied with a trickle system. Food, Agriculture \& Environment, 1: 198-202.

Ziaul, H.M., Zaber, H.M. 2013. Impact of salinity on livelihood strategies of farmers. Journal of Soil Science and Plant Nutrition, 13: 417-431. 